\title{
Solubilization of Rock Phosphate by Spent Wash Solubilization of Phosphorus from Low-Grade Udaipur Rajasthan Rock Phosphate Using Spent Wash from Faizabad, Utter Pradesh, India
}

\author{
Balu Ram*, Ramawatar Meena and Raj Kumar Meena \\ Department of Soil Science \& Agricultural Chemistry, Institute of Agricultural Sciences, \\ Banaras Hindu University, Varanasi-221005, India \\ *Corresponding author
}

A B S T R A C T

\begin{tabular}{|l|}
\hline Ke y w o r d s \\
Phosphorus fetilizers, \\
Rock phosphorus, \\
Spent wash \\
\hline Article Info \\
\hline $\begin{array}{l}\text { Accepted: } \\
\text { 15 September } 2018 \\
\text { Available Online: } \\
\text { 10 October } 2018\end{array}$ \\
\hline
\end{tabular}

High-grade rock phosphate $\left(\mathrm{P}_{2} \mathrm{O}_{5}>30 \%\right)$ is essential for manufacturing $\mathrm{P}$ fertilizers. only $39 \%$ is of high grade which could meet hardly $35-40 \%$ of the demand of $\mathrm{P}$ fertilizers (Indian Bureau of Mines 2014). In India, there is a predominance of low grade rock phosphate reserves and out of 260 million ton only 15.3 million ton is of high grade quality. The consumption of apatite and rock phosphate in 2011-12 was about 3.96 million tonne. Rock phosphate is usually inert in alkaline and calcareous soils. While exploring the options available for increasing the solubility of low grade RP, it was thought that the spent wash which is highly acidic (pH: 3.5-4.5) and generated as a waste in huge quantities $\left(6.8 \times 10^{10}\right.$ litres/year) in the country, may be utilized for this purpose. Spent wash has considerable manurial potential. The extent of P-solubilization from low-grade Udaipur rock phosphate (RP) by spent wash (SW) was studied by mixing RP and SP in different ratios i.e. $1: 1,1: 2,1: 5,1: 10,1: 20,1: 40,1: 60,1: 80$ and 1:100. The amount of phosphorus solubilized, increased with increasing rate up to RP: SW::1: 20 and thereafter, smaller increase solubilized phosphorus.

\section{Introduction}

The concept of P solubilising an eco-friendly alternative for utilizing abundant resources of low grade rock phosphate which is unacceptable to the $\mathrm{P}$ fertilizer industry and the spent wash-a foul smelling, highly acidic, waste water from the distilleries, which poses the problem of environmental pollution. Due to highly acidic nature of the SW, it appeared that it may have the potential to solubilize $\mathrm{P}$ from low-grade RP. In India, Total resources of rock phosphate and apatite as per UNFC system as on 1.4.2010 are placed at 296.3 and 24.23 million tonnes receptively and The consumption of apatite and rock phosphate in 2011-12 was about 3.96 million tonnes

Rock phosphate is one of the basic raw materials needed in the manufacture of phosphatic fertilizers like single super phosphate, diammonium phosphate, nitro phosphates etc. Commercial rock phosphate occurs in nature as deposits of apatites $(\mathrm{P}$ bearing minerals) along with other accessory minerals such as quartz, silicates, carbonates, 
sulphates, sesquioxides etc. Four types of rock phosphate minerals are: Carbonate apatite $\left[3 \mathrm{Ca}_{3}\left(\mathrm{PO}_{4}\right)_{2} \cdot \mathrm{CaCO}_{3}\right]$, Fluoro apatite $\left[3 \mathrm{Ca}_{3}\right.$ $\left.\left(\mathrm{PO}_{4}\right)_{2} \cdot \mathrm{CaF}_{2}\right]$, Hydroxy apatite $\left[3 \mathrm{Ca}_{3}\left(\mathrm{PO}_{4}\right)_{2} \cdot \mathrm{Ca}(\mathrm{OH})_{2}\right]$, Sulpho apatite $\left[3 \mathrm{Ca}_{3}\right.$ $\left.\left(\mathrm{PO}_{4}\right)_{2} \cdot \mathrm{CaSO}_{4}\right]$. The apatites of igneous and metamorphic origin are generally regarded as less reactive because of their well-developed crystalline form. However, the apatites of sedimentary rock deposits are soft minerals possessing micro-crystalline structure and are of major commercial importance for direct application in the soil (Narayanasamy and Biswas, 2002).

In recent years, due to expansion of distilleries in sugar cane growing countries, the disposal of spent wash has become an acute problem. In India, about 15,000 million liters of spent wash is produced annually from 246 distilleries which is characterized by undesirable color, foul odor, high biological oxygen demand (BOD: 5,000-8,000 $\mathrm{mg} \mathrm{l}^{-1}$ ) and chemical oxygen demand (COD: 25,000$30,000 \mathrm{mg}^{-1}$ ) (Joshi et al., 1996). Such situation has created an acute problem of spent wash disposal with the expansion of distilleries in the sugarcane growing countries. Which is highly acidic ( $\mathrm{pH} 3.5-4.5)$ and generated in huge quantities $\left(6.8 \times 10^{10} \mathrm{~L} \mathrm{yr}^{-1}\right)$ in the country having considerable manurial potential (Chhonkar et al., 2000; Kumari and Phogat, 2010), as well as problem of disposal. It will be worthwhile to study the effect of spent wash on $\mathrm{P}$ solubilization from indigenous low-grade rock phosphate. As spent wash is very harmful to aquatic fauna and flora if discharged directly into water bodies, land disposal is the only option.

For the manufacture of phosphatic fertilizers, a high grade quality rock phosphate $(>30 \%$ $\mathrm{P}_{2} \mathrm{O}_{5}$ ) is required. But in India, there is a predominance of low grade rock phosphate reserves and out of 260 million ton of indigenous deposits of rock phosphate only
15.3 million ton is of high grade quality (Narayansamy and Biswas, 1998). Current annual demand of rock phosphate as a source of phosphatic fertilizer is about 4 million ton but its production is only about 1.4 million ton which could meet hardly $35 \%$ of the total demand. The remaining demand of rock phosphate is met through its imports. In order to reduce this cost, it becomes necessary to generate technologies/methodologies by which phosphorus from indigenous low grade rock phosphate can be solubilized. Rock phosphate is considered as a slow release fertilizer, is cheaper than any other phosphatic fertilizers and also has a longer residual effect. Its phosphorus is solubilized only in acidic environment. Therefore, it can only be used efficiently in acidic soils. It is usually inert in alkaline and calcareous soils (Rahman and Singh, 2004). It could be converted into a potential resource of phosphorus with the use of low energy inputs and in an eco-friendly manner so that it may also be used in neutral and alkaline soils. It was thought that the waste water from distillery (distillery effluent or spent wash) which is highly acidic ( $\mathrm{pH} 3.5-$ $4.5)$ and produced in huge quantity $\left(6.8 \times 10^{10}\right.$ litres/year) in the country and have a problem of its disposal, may be utilized for solubilization of phosphorus from indigenous low grade rock phosphate. Apart from its highly acidic nature, spent wash also contains appreciable amount of both macro and micronutrients i.e. it has considerable manurial potential (Chhonkar et al., 2000).

Phosphorus is one of the critical nutrient elements which plays important role in increasing crop growth and crop yield. When $\mathrm{P}$ is applied in soil through fertilizers, its recovery by crops in a growing season is very low (15-20\%). More than $80 \%$ of the $\mathrm{P}$ gets rapidly fixed into insoluble compounds as $\mathrm{Ca}$ $\mathrm{P}$ in alkaline, and as Fe-P and Al-P in acid soils. At any time, the average concentration of soluble $\mathrm{P}$ in soil ranges from 0.05 to 10 
ppm, out of which only an infinitesimal part is available to plant (Bhattacharyya and Jain, 2000). Apart from this, $P$ in soil moves mainly by diffusion and its rate of diffusion is very slow (10-12 to $10-15 \mathrm{~m} 2$ sec-1). Since the $\mathrm{P}$ uptake rate by crops is quite high, it creates a zone around the roots that is depleted of P. In order to maintain optimum $\mathrm{P}$ concentration in the root zone, it becomes necessary to regularly supplement the soil with phosphatic fertilizers. Like N, P is also required in large amounts by crops, therefore, a large amount of phosphatic fertilizers is needed for sustaining the crop production to meet the food and other requirements of the growing population of the country.

\section{Materials and Methods}

Finely ground 100 mesh low grade Udaipur Rock Phosphate (URP) which is sold under the brand name 'Rajphos' procured from Rajasthan State Mines and Minerals Ltd., Udaipur, Rajasthan was used for the study. Some of the selected characteristics/constituents of URP are presented in Table 1.The spent wash (SW) was collected from the K.M. Sugar Mill Faizabad, Utter Pardesh.

All the physico- chemical analysis was conducted in laboratory of the Department of Soil Science \& Agricultural Chemistry, Institute of Agricultural Sciences, BHU, Varanasi and some of the selected characteristics/constituents of SW are presented in Table 2. The extent of Psolubilization from lowgrade Udaipur rock phosphate (RP) by spent wash (SW) was studied by mixing RP and SP in different ratios. The RP:SW ratios were 1:1, 1:2, 1:5, $1: 10,1: 20,1: 40,1: 60,1: 80$ and 1:100. To obtain these ratios $100,50,20,10,5,2.5,1.7$, $1.25,1.0 \mathrm{~g}$ of RP was mixed in $100 \mathrm{ml}$ of SW in plastic bottles in triplicates. These bottles were agitated on a mechanical shaker for one hour and then the suspension obtained was filtered through Whatman No. 40 filter paper. The filtrate thus obtained was analyzed for $\mathrm{pH}$ (Systronics Digital pH meter), electric conductivity (Elico Conductivity Bridge), and soluble P, fluorine (Orion, 1991). Soluble P in the filtrate was determined by digesting the filtrate as per procedure used for the determination of total $\mathrm{P}$ because there was a problem in getting the colourless filtrate even after repeated leaching with Darco-G 60. The colour of the filtrate was actually the colour of the spent wash which was interfering in the development of colour for the estimation of soluble $\mathrm{P}$ by Watanabe and Olsen (1965) method. The amount of $\mathrm{P}$ thus obtained was designated as soluble $\mathrm{P}$ but in fact this $\mathrm{P}$ was spent wash extractable $\mathrm{P}$ of the rock phosphate.

\section{Results and Discussion}

The extent of $\mathrm{P}$ solubilized from indigenous low grade rock phosphate and the trend observed for the change in $\mathrm{pH}$ upon mixing of rock phosphate and spent wash in different ratios is presented in Table 3 . The $\mathrm{pH}$ of the mixture of RP: SW in the ratio of $1: 1$ was 6.67 which reduced upon dilution of RP with SW. This value, however, reduced to as low as 4.21 for the mixture of RP: SW::1: 100 which was almost equivalent to the $\mathrm{pH}$ of the fresh spent wash.

The decrease in the $\mathrm{pH}$ of the mixtures, mixed in different ratios of RP and SW maybe due to dilution of RP with acidic $\mathrm{SW}(\mathrm{pH}=4.2)$. The EC of the filtrates did not change much and remained between the range of 18.2 and 19.2 $\mathrm{dSm}^{-1}$ which is almost similar to the EC of spent wash itself. From these values, it appears that the EC of the RP, which was recorded to be $1 \mathrm{dS} \mathrm{m}^{-1}$ (Table 3), did not contribute much to the EC of the extract and it was spent wash, which wholly contributed to its soluble salt content. 
Table.1 Constituents of Udaipur rock phosphate on oven dry basis

\begin{tabular}{|c|}
\hline Constituents \\
\hline $\mathrm{pH}(1: 2.5)$ \\
\hline $\mathrm{EC}(1: 2.5)$ \\
\hline Total $\mathrm{P}_{2} \mathrm{O}_{5}(\%)$ \\
\hline Citrate Soluble $\mathrm{P}_{2} \mathrm{O}_{5}(\%)$ \\
\hline Water Soluble $\mathrm{P}_{2} \mathrm{O}_{5}(\%)$ \\
\hline
\end{tabular}

\begin{tabular}{|c|}
\hline Contents \\
\hline 7.36 \\
\hline $0.64 \mathrm{dSm}^{-1}$ \\
\hline $18.5 \%$ \\
\hline $14 \%$ \\
\hline Traces \\
\hline
\end{tabular}

Table.2 Physico-chemical properties of the spent wash of K. M. Sugar Mill

Faizabad, Utter Pardesh

\begin{tabular}{|c|}
\hline Property \\
\hline pH $(1: 2.5)$ \\
\hline EC $(1: 2.5)$ \\
\hline Total N \\
\hline Total P \\
\hline Total K \\
\hline
\end{tabular}

\begin{tabular}{|c|}
\hline Contents \\
\hline 4.2 \\
\hline $19 \mathrm{dSm}^{-1}$ \\
\hline $1242 \mathrm{mgl}^{-1}$ \\
\hline $28 \mathrm{mgl}^{-1}$ \\
\hline $6735 \mathrm{mgl}^{-1}$ \\
\hline
\end{tabular}

Table. $3 \mathrm{pH}, \mathrm{EC}$, soluble $\mathrm{P}$ in the filtrate of the mixtures of rock phosphate and spent wash in different ratios

\begin{tabular}{|c|c|c|c|}
\hline RP:SW ratio & $\mathrm{pH}$ & $\mathrm{EC}\left(\mathbf{d S m}^{-1}\right)$ & Soluble P $(\mathbf{p p m})$ \\
\hline $1: 1$ & 6.67 & 18.4 & 36 \\
\hline $1: 2$ & 6.12 & 18.2 & 168 \\
\hline $1: 5$ & 5.37 & 18.2 & 367 \\
\hline $1: 10$ & 4.64 & 18.3 & 790 \\
\hline $1: 20$ & 4.52 & 18.4 & 1230 \\
\hline $1: 40$ & 4.38 & 18.5 & 1360 \\
\hline $1: 60$ & 4.28 & 18.7 & 1490 \\
\hline $1: 80$ & 4.22 & 18.9 & 1510 \\
\hline $1: 100$ & 4.21 & 19.2 & 1520 \\
\hline
\end{tabular}

The prime objective, however, was to study the extent of P solubilization from RP upon mixing it with highly acidic SW. The values of soluble $\mathrm{P}$ obtained for different ratios of RP: SW (Table 3) showed that the use of increasingly higher volume of SW resulted in increased solubility of P from RP, however, the per cent solubilization varied with the ratio. For the ratio of $1: 1$ only $36 \mathrm{ppm}$ of $\mathrm{P}$ was solubilized by the SW. The magnitude of $\mathrm{P}$ solubilisation increased to $168 \mathrm{ppm}$ for the ratio 1:2. Likewise, the amount of $P$ solubilized raised to $367,790,1230,1360$, $1490,1510,1520 \mathrm{ppm}$ as the ratio increased gradually in the order 1:5, 1:10, 1:20, 1:40, $1: 60, \quad 1: 80, \quad 1: 100, \quad$ respectively. The magnitude of increase in the amount of $\mathrm{P}$ solubilized, increased with increasing rate up to RP: SW ratio of 1:20 and thereafter, this magnitude increased but with a decreasing rate. The explanation behind this increase in $\mathrm{P}$ solubilization lies in the $\mathrm{pH}$ values of the 
extract of the respective ratio. The extract of the mixture containing RP: $\mathrm{SW}$ in a ratio of 1:1 registered only $36 \mathrm{ppm}$ of soluble $\mathrm{P}$ and recorded a maximum $\mathrm{pH}$ of 6.67. The increase in $\mathrm{pH}$ of SW from 4.2 to 6.67 may be attributed to the mixing of SW with RP having a $\mathrm{pH}$ of 7.36 and after one hour of mixing the system tend to equilibrate at $\mathrm{pH}$ 6.67. Upon widening the ratio of RP and SW, the $\mathrm{pH}$ of the suspension decreased which resulted in higher amount of $\mathrm{P}$ solubilized. But beyond the ratio of 1:20, although $\mathrm{pH}$ of the suspension remained almost the same, but the amount of $\mathrm{P}$ solubilized did not increase much indicating the potential limit of SW to solubilize $\mathrm{P}$ from the low grade rock phosphate. The volume of SW in the RP: SW ratio of 1:20 appears to be enough to bring all the particles of the RP in contact with the sufficient amount of SW to extract the $\mathrm{P}$ to the maximum possible extent. The filtrate obtained by mixing the RP and SW in the ratio of 1:20, was found to have $1230 \mathrm{ppm}$ of soluble P. As the amount of 28 ppm of P was present in the SW, therefore, SW solubilized about $1202 \mathrm{ppm}$ or $1.2 \mathrm{mg}$ of $\mathrm{P}$ from $80 \mathrm{mg}$ of the total $\mathrm{P}$ contained in the $\mathrm{RP}\left(18.6 \% \mathrm{P}_{2} \mathrm{O}_{5}\right)$.

Spent wash being a very acidic (pH- 4.2) medium can be tried for the solubilization of $\mathrm{P}$ from the rock phosphate. On mixing SW and RP in different ratios, although amount of $\mathrm{P}$ solubilized increased from $36 \mathrm{ppm}$ (1:1) to $1520 \mathrm{ppm}$ (1:100). But the magnitude of increase, increased with increasing rate up to the ratio of RP: SW::1: 20 and thereafter, this magnitude increased but with a decreasing rate.

\section{References}

Bhattacharyya, P. and Jain, R.K. (2000). Fert. News 45:45-52.

Biswas, D.R. and Narayanasamy, G. (2002). Fert. News, 47: 53-56.

Chhonkar, P.K. et al., (2000). J. Scientific Indus. Res., 59: 350-361.

Kumari, Kiran and Phogat, V.K. (2010) Characterization of spent wash from different distilleries operating in Haryana and its utilization as a source of liquid manure in agriculture. Journal of the Indian Society of Soil Science58, 347-351.

Narayanasamy, G. and Biswas, D.R. (1998). Fert. News, 43: 21-32.

Orion. (1991). Fluoride instruction manual. Orion Research Institute, USA.

Rahman, F.H. and Singh, J. K. (2004). Environment and Ecology, 22: 48-51

Watanabe, F.S. and Olsen, S.R. (1965). Proc. Soil Sci. Soc. Am., 29: 677-678

\section{How to cite this article:}

Balu Ram, Ramawatar Meena and Raj Kumar Meena. 2018. Solubilization of Rock Phosphate by Spent Wash Solubilization of Phosphorus from Low-Grade Udaipur Rajasthan Rock Phosphate Using Spent Wash from Faizabad, Utter Pradesh, India. Int.J.Curr.Microbiol.App.Sci. 7(10): 1934-1938. doi: https://doi.org/10.20546/ijcmas.2018.710.222 